\title{
On the sentence-internal reading of French le même ('the same')
}

\author{
Isabelle Charnavel \\ University of California, Los Angeles \\ Institut Jean Nicod-Ecole Normale \\ Supérieure, Paris
}

\begin{abstract}
This paper focuses on the sentence-internal reading of French le même and addresses two main issues:

(i) the problem of definiteness (le même does not behave the way standard definites do);

(ii) the problem of compositionality (the plural licenser that le même needs to get interpreted is not adjacent to it).

I propose that:

(i) le même is a complex determiner with specific properties with respect to presupposition and specificity;

(ii) le même is an existential quantifier over a plural event that is partitioned along participants or times. This licensing condition (plural event distributed through participants or times) relates même to the notion of pluractionality.
\end{abstract}

Keywords: same; definiteness; event; French

\section{Introduction}

Same and different are often used as tools to disambiguate scope: in (1), the addition of different can disambiguate the wide scope of every (a different woman loves every man), while that of same can clarify its narrow scope (the same woman loves every man).

\section{(1) A woman loves every man.}

This paper supposes that these expressions themselves are worth investigating and specifically concentrates on the sentence-internal reading of French le même 1

1 Even if it would seem natural to study the two expressions même 'same' and différent 'different' together, I only focus on même here: because of several important differences, a detailed comparison of the two expressions would go beyond the scope of this paper. 
On the sentence-internal reading of French le même ('the same')

'the same' as a case study.

(2) Luc et Flore ont lu le même livre.

"Luc and Flore read the same book."

A sentence-internal reading (cf. Carlson 1987 for same) refers to a reading where même 'same' gets interpreted without calling for sentence-external elements: (2) means that the book that Luc read is identical to the book that Flore read, or in other terms, Luc and Flore read the same book. This reading differs from so-called sentence-external readings in which the element of comparison is given by the context, whether deictically (3) or anaphorically (4): (3) means that Luc and Flore read the same book as a book that is pointed to in the situation; in (4), Luc and Flore read the same book as a book previously mentioned in the discourse.

(3) Regarde! Luc et Flore ont lu le même livre.

"Look! Luc and Flore read the same book."

(4) J'ai lu Germinal pendant les vacances. Luc et Flore ont lu le même livre.

"I read Germinal in the holidays. Luc and Flore read the same book."

Moreover, these two uses in which the comparison is implicit differ from another use involving overt comparison (comparative construction):

(5) Luc et Flore ont lu le même livre que toi/l'année dernière/celui que tu as emprunté à la bibliothèque.

"Luc and Flore read the same book as you/last year/the one you borrowed from the library."

In this paper, I focus on the sentence-internal reading of le même and address two problems ${ }^{2}$ raised by this construction (as already observed for same by Carlson (1987) and Barker (2007) among others):

- the problem of definiteness: even if the definite determiner is used in this construction (le même 'the same'), it does not exhibit the usual properties of the definite article.

2 Même 'same' also raises the problem of type/token ambiguity:

(i) Luc et Flore ont lu le même livre. 'Luc and Flore read the same book.'

a. Luc read a certain copy of a book, and Flore read this copy too. (token reading)

b. Luc read a certain book, Flore also read this book, but not the same copy. (type reading)

This problem is however orthogonal to the problems I address here. 
- the problem of compositionality: the interpretation of même relies on the presence of a licenser that is not directly combined with the DP involving même (cf. in (2): Luc et Flore 'Luc and Flore').

To address these issues, I propose an analysis in terms of events: I claim that le même is syntactically a complex determiner that undergoes quantifier raising, and semantically an existential quantifier over a plural event that has been distributed through participants or times.

\section{The problem of definiteness: le même as a complex determiner}

The first problem that the sentence-internal reading of même raises is the problem of definiteness: while involving a definite article, le même does not exhibit the properties that typical definite descriptions do. ${ }^{3}$

\subsection{Presuppositions}

In particular, le même does not trigger presupposition of unique existence as already suggested by Barker (2007) for same. Basic tests for presuppositions show that while le livre bleu 'the blue book' in (7a) presupposes the existence of a unique blue book, le même livre 'the same book' in (6a) does not presuppose the existence of a unique book: whether or not there is a unique book that the children read is precisely what is at issue in (6b) and negated in (6c).
a. Luc et Flore ont lu le même livre.
"Luc and Flore read the same book."
b. Est-ce que Luc et Flore ont lu le même livre?
"Did Luc and Flore read the same book?"
c. Luc et Flore n'ont pas lu le même livre.
"Luc and Flore did not read the same book."
(7) a. Luc et Flore ont lu le livre bleu.
"Luc and Flore read the blue book."
b. Est-ce que Luc et Flore ont lu le livre bleu?
"Did Luc and Flore read the blue book?"
c. Luc et Flore n'ont pas lu le livre bleu.
"Luc and Flore did not read the blue book."

3 Note that interestingly, French même also combines with the indefinite article un, as opposed to English same.

(ii) Quatre générations sous un même toit. 'Four generations under one same roof.'

The use of un même is however a puzzle in itself, which would be worth another paper (cf. Charnavel 2011. 
On the sentence-internal reading of French le même ('the same')

Moreover, le même can introduce a new discourse referent as opposed to standard definite articles. The following dialogue where no book was alluded to before is perfectly felicitous:
A: Pourquoi tu penses que Luc et Flore ont des goûts similaires?
B: Pendant les vacances, ils ont lu le même livre.
"A: Why do you think Luc and Flore have similar tastes?
B: They read the same book during the holidays."

Le même exhibits an existential flavor similar to indefinite articles: (8) means that there exists a unique book that both Luc and Flore read; the existence of this book is not presupposed.

The fact that le même - as opposed to le 'the' or ce 'this' - can occur in existential constructions corroborates this observation.

(9) a. Il existe le même problème dans ces trois pays.

"There exists the same problem in these three countries."

b. *Il existe le/ce problème dans ces trois pays.

"*There exists the/this problem in these three countries."

All these facts suggest that le même does not trigger a presupposition of unique existence. However, this is only true locally, i.e. at the DP level (le même livre in (6a)). Le même however triggers a global presupposition, i.e. at the sentence level: in (6), it is presupposed that Luc and Flore each read a book; the question is then to know whether they read the same one. ${ }^{4}$ Thus, the following dialogue is unfelicitous:

A:Est-ce que Luc et Flore ont lu le même livre?

B:\# Non, Luc n'a pas lu de livre.

"A: Did Luc and Flore read the same book?

B:\# No, Luc didn't read any book."

It is less clear whether le même triggers a global presupposition of uniqueness, but the weirdness of the following sequence rather suggests it does (cf. Solomon

4 At first glance, this seems to be different when the licenser is adverbial: (iii) does not necessarily presuppose that Luc always reads books, but (iii) may mean that the few times Luc reads books, they are the same.

(iii) Luc lit toujours le même livre. 'Luc always reads the same book.'

However, this is only due to the vagueness of the notion of times (as opposed to weeks for example) included in always: (iv) clearly presupposes that Luc reads a book every week:

(iv) Luc lit toutes les semaines le même livre. 'Luc reads the same book every week.' 
Isabelle Charnavel

2009 for English same).

(11) ?Luc et Flore ont lu le même livre pendant les vacances, et Luc a également lu les Misérables et Madame Bovary.

"Luc and Flore read the same book during the holidays, and Luc also read les Misérables and Madame Bovary."

However, the hypothesis of a global uniqueness presupposition is often tied to the possibility of domain restriction:
a. Luc et Flore ont le même professeur.
"Luc and Flore have the same teacher."
b. Luc et Flore ont le même stylo.
"Luc and Flore have the same pen."

In both cases (12a-12b), it is clear that Luc et Flore have more than one teacher or pen; however, le même is felicitous. But it remains unclear whether it is because it does not involve any uniqueness presupposition, or because the uniqueness presupposition is associated with domain restriction.

To summarize, le même does not behave like the standard definite article in that it does not trigger a local presupposition of unique existence. However, it triggers a global presupposition of (possibly unique) existence.

\subsection{Specificity}

Le même also exhibits unexpected properties with respect to specificity. Following Enç (1991), I assume that specificity corresponds to an inclusion relation in a contextually determined set. According to Enç, since identity of referents entails inclusion, all definites are specific. However, le même departs from standard definites in this respect: two readings are available in $(13),{ }^{5}$ as is the case with indefinites.

(13) Claire et Flore ont acheté la même robe.

"Claire and Flore bought the same dress."

a. Specific: there is a particular dress that the speaker has in mind that Claire and Flore each bought.

b. Non specific: there exists a unique dress - whatever it is, the speaker does not know which one - that Claire and Flore each bought.

5 More than two readings are involved if one incorporates the type/token and the external/internal ambiguities, which I do not do here since I focus on the specificity effect. 
On the sentence-internal reading of French le même ('the same')

\subsection{DP-internal distribution of même}

In this section, I show that même does not exhibit the DP-internal distribution of standard adjectives (illustrated by beau 'beautiful' here), which supports the hypothesis that le même is actually a complex determiner. ${ }^{6}$

First, même cannot be used predicatively.

a. Ces livres sont *(les) mêmes.

"These books are *(the) same."

b. Ces livres sont (*les) beaux.

"These books are (*the) beautiful."

a. *Je ne le trouve pas même aujourd'hui.

"*I don't find him same today."

b. Je ne le trouve pas beau aujourd'hui.

"I don't find him beautiful today."

Moreover, the only determiners compatible with sentence-internal même are the definite determiner le/les (singular and plural), and the indefinite one un (only singular) in certain contexts. ${ }^{7}$

a. Luc et Flore ont lu*quelques/*divers/*certains/*plusieurs/*trois/*des lles mêmes livres.

"Luc and Flore read $*$ some $/ *$ various $/ *$ certain $/ *$ several $/ *$ three $/ * \varnothing /$ the same books."

b. Luc et Flore ont lu ?un/*leur/\#ce/le même livre.

"Luc and Flore read *a/*their/\#this/the same book."

c. Luc et Flore ont lu quelques/divers/certains/plusieurs/trois/de/les beaux livres.

"Luc and Flore read some/various/certain/several/three/ $\varnothing /$ the beautiful books."

d. Luc et Flore ont lu un/leur/ce/le beau livre.

"Luc and Flore read a/their/this/the beautiful book."

6 There is some crosslinguistic evidence for this hypothesis: for example in Romanian (as already noted by Brasoveanu (2008)), while singular and plural 'different' are adjectival in nature (alt and diferit, respectively), 'same' is a determiner - the so-called demonstrative article (or pronoun) of identity acelaşi (agreeing in gender and number), which is the counterpart of the English 'the+same' rather than just 'same'. Thanks to Dana Manescu for providing me the following data:

(v) Jean si Marie au citit aceeasi carte. 'Jean and Marie read the same book.'

7 Note also very restricted expressions where no determiner is required at all:

(vi) a. Ils étaient de même taille. 'They were of same height.'

b. Ils avaient même allure. 'They had same look.' 
Furthermore, même cannot be modified by adverbs.

(17) Luc et Flore ont lu le (*vraiment/*très/*presque/*tout) même livre. "Luc and Flore read the (?really/very/?almost/very) same book."

Finally, même cannot be coordinated with any adjective.

(18) Luc et Flore ont acheté le (*petit et/*premier et/*seul et) même livre.

"Luc and Flore bought the (*small and/*first and/*only and) same book."

All these facts lead me to hypothesize that le même is a complex determiner with mixed properties with respect to definiteness: it exhibits indefiniteness effects with respect to local presuppositions (there is no presupposition of unique existence at the DP level) and specificity (specific and non specific readings are both available); however, existence and possibly uniqueness presuppositions arise at a global, i.e. sentential level. ${ }^{8}$

\section{The problem of compositionality: le même as an existential quantifier over events}

The second issue raised by le même relates to compositionality. The point is that sentence-internal le même requires a plural licenser to get interpreted; and the licenser does not directly combine with le même since it is not adjacent to it.
a. $\#^{9}$ Luc a lu le même livre.
"Luc read the same book."
b. Luc et Flore ont lu le même livre.
"Luc and Flore read the same book."

\subsection{Distributivity}

As already mentioned by Carlson (1987) for same, distributivity is crucial to license sentence-internal le même: only distributive licensers are compatible with le

8 A potential problem with this hypothesis is the fact that numerals can occur between les and mêmes:

(vii) les deux mêmes livres 'the two same books'

Moreover, note that même can be coordinated with some adjectives when used with the indefinite determiner $u n$ :

(viii) a. un seul et même livre 'one and the same book'

b. un unique et même livre

9 \# indicates that the sentence-internal reading is not available (but the sentence-external reading is available if the right context is set up). 
On the sentence-internal reading of French le même ('the same')

même, whether obligatorily distributive (some quantifiers, cf. (20a)) or optionally distributive (plurals, cf. (20b), and conjunctions, cf. (20c)).
a. Chaque enfant a lu le même livre.
"Each child read the same book."
b. Ces enfants ont lu le même livre. "These children read the same book."
c. Luc et Flore ont lu le même livre.
"Luc and Flore read the same book."

This means that elements that cannot be distributive (singulars cf. (21a), collectives cf. (21b) and (21c) ${ }^{10}$, mass nouns cf. (21d)) cannot license le même.

(21) a. \#Luc a lu le même livre.

"\# Luc read the same book."

b. \#J'ai présenté des enfants au même animateur.

"? I introduced children to the same organizer."

c. \#La classe a lu le même livre.

"? The class read the same book."

d. \#Le riz coûte le même prix

"\# Rice costs the same prize."

\subsection{Le même and syntactic movement}

\subsubsection{Quantifier raising}

Since le même and its licenser are not adjacent but need to combine together for interpretive purposes, the question is to know which relation is involved between these two elements.

First, le même does not behave like an anaphor, since le même does not need to be c-commanded by its antecedent.

(22) Le même joueur a remporté tous les tournois.

"The same player won every tournament."

Moreover, the following examples (where the sentence-internal reading is not available) give some evidence for LF movement of le même. They show that le même is sensitive to island constraints (adjunct constraint (23a), coordination constraint (23b), extraction constraints related to non bridge-verbs (23c), factive verbs (23d),

10 French indefinite plural article des only triggers collective readings as opposed to the definite plural les that yields distributive or collective readings of the DP it is the head of. 
wh-islands (23e), and subject islands (23f)).

(23) a. \#Aucun enfant n'est en colère parce que la même fille a été élue.

"No child is angry because the same girl got elected."

b. \#Aucun étudiant n'a rencontré Luc et la même femme.

"No student met Luc and the same woman."

c. \#Tous les habitants chuchotent que la même personne a commis le crime.

"Every inhabitant whispers that the same person committed the crime."

d. \#Tous les habitants savent que la même personne est venue.

"Every inhabitant knows that the same person came."

e. \#Anne et Flore se demandent quand la même personne viendra.

"Anne and Flore wonder when the same person will come."

f. \#Que Luc ait commis le même crime effraie Anne et Flore.

"That Luc committed the same crime frightens Anne and Flore."

These examples suggest that le même undergoes the same kind of movement as scope-taking elements different from indefinites (that are not sensitive to islands), namely quantifiers. ${ }^{11}$

To sum up, the relation between the licenser and le même resembles the relation between two scope-taking quantifiers. More precisely, since I showed in the previous section that le même is a complex determiner, I hypothesize that le même pied-pipes its NP complement, as standardly assumed for quantifiers like every.

To identify more precisely the landing site of le même NP, I will now examine scope phenomena.

11 A potential problem is that while quantifier raising - as opposed to wh-movement - is standardly assumed to be clause bounded, the following sentences are not completely ungrammatical (at least for some speakers of French).

(ix) a. ? Luc et Flore pensent qu'Anne apportera le même dessert.

'Luc and Flore think that Anne will bring the same dessert.'

b. ? Luc et Flore pensent que le même homme remportera l'élection.

'Luc and Flore think that the same man will win the election.'

(x) ? Luc et Flore ont émis l'opinion que la même personne devrait être renvoyée.

'Luc and Flore expressed the opinion that the same person should be dismissed.'

Nevertheless, this problem can be minimized given that some quantifiers also exhibit the same tendency to sometimes scope outside their tensed clause ("scope out" phenomenon), as illustrated in the following sentence where both the wide-scope and the narrow-scope readings of every are available.

(xi) One girl knows what every boy bought for Mary. 
On the sentence-internal reading of French le même ('the same')

\subsubsection{Scope phenomena}

Scope interactions between le même, tous 'all' and the negation shed light on asymmetries between le même $N P$ as subject and object.

(24) Tous les enfants n'ont pas lu le même livre.

"All the children did not read the same book."

a. $\neg>$ même: it is not the case that all the children read a unique book.

b. *même $>\neg$ : all the children omitted to read a unique book.

In (24), there is only one available reading; so when le même NP is object, it cannot scope over the negation. ${ }^{12}$

The situation is however different when le même NP is subject; in this case, two readings are available:

(25) Le même enfant n'a pas lu tous les livres.

"The same child did not read all the books."

a. $\neg>$ même: it is not the case that a unique child read all the books.

b. même $>\neg$ : a unique child omitted to read all the books.

This shows that le même NP can scope over the negation only when it is subject. Therefore, le même object has to move to a position occurring below the negation. However, (25b) is possible because subject le même scopes over the negation in its surface position.

To summarize, le même NP seems to behave like a scope-taking quantifier that undergoes quantifier raising. Moreover, scope interactions with negation indicate that object le même NP moves between the negation and the VP. This fact makes syntactically plausible the event hypothesis proposed in the next section, given the position of the event variable in the structure.

\section{The event hypothesis}

Carlson (1987) and Moltmann (1992) argue for an analysis of same (and different) in terms of events, based on the fact that same is not only licensed by distributive DPs, but also by conjoined PPs, conjoined Ps, conjoined VPs, conjoined Vs, conjoined APs and possibly conjoined Advs. Examples involving different are as follows (from

12 In French, it is rather ne than pas that represents the abstract position of the negation. 
Isabelle Charnavel

Carlson 1987: 538):
a. Different people discovered America and invented bifocals.
b. John saw and reviewed different films.
c. Max put different plates on the table and in the cupboard.
d. Different people voted for and against the proposal.
e. John painted different houses very red and somewhat blue.
f. (?) John does different tasks eagerly and grudgingly.

They conclude from such examples that same combines with a plural eventuality rather than a DP. ${ }^{13}$

The same kinds of examples hold in French too.
a. Le même homme composait des opéras et s'endettait régulièrement. "The same man composed operas and got into debts."
b. Le même homme composait et jouait des sonates. "The same man composed and played sonatas."
c. Le même homme aimait peindre dans son atelier et à l'extérieur. "The same man liked painting in his studio and outside."
d. Le même homme a voté pour et contre le projet de loi. "The same man voted for and against the bill."
e. Luc a peint le même jouet en rouge et en bleu. "Luc painted the same toy in red and in blue."
f. Luc a cuisiné le même plat hier et aujourd'hui. "Luc cooked the same meal yesterday and today."

Moreover, même is not only licensed by conjoined elements, but also by other contexts involving plural events (which to my knowledge have not been mentioned in the literature yet). They involve several possible aspectual notions, which can be expressed by several categories (verbs, adverbs, preverbs, nouns, adjectives).

13 However, these cases are not full proof arguments in favor of an event analysis: it is possible (if one treats coordination as quantification) to say that le même requires quantification. That's basically Barker's (2007) analysis, which argues that same takes parasitic scope between another quantifier and the nuclear scope of that quantifier. Moreover, since Barker works in a continuation framework, he can say that this quantifier can be of any category (variable $X$ ): the denotation for same is then type-polymorphic. To this end, Barker assumes that the relevant semantic domains have a boolean structure, including at least closure under a join operation.

However, this kind of analysis is hard to implement in a standard framework. Furthermore, the other data I present suggest that an event analysis seems to be more appealing. 
On the sentence-internal reading of French le même ('the same')

\section{Frequentativity}

(28) a. Lucie commet souvent la même erreur.

"Lucy often makes the same mistake."

b. Antoine a lu le même livre plusieurs fois.

"Antoine read the same book several times."

c. Le film s'arrête à chaque fois sur la même image.

"The movie stops every time on the same picture."

\section{Iterativity}

(29) a. La répétition de la même erreur n'est pas acceptable. "The repetition of the same mistake is not acceptable."

b. La deuxième/troisième/quatrième édition du même livre.

"The second/third/fourth edition of the same book."

\section{Habituativity}
a. Il invite habituellement les mêmes personnes chez lui. "He usually invites the same people at his place."
b. Il avait coutume d'inviter les mêmes personnes chez lui. "He used to invite the same people at his place."

\section{Continuativity}

a. Il est difficile de continuer à travailler dans la même entreprise quand on aime le changement.

"It is hard to keep working in the same company when one likes changes."

b. Le maintien dans le même établissement est de règle pour tout étudiant admis en seconde année ou autorisé à redoubler. [google]

"The maintenance in the same establishment is usual for every student admitted in second year or permitted to repeat the year."

c. Il a un désir constant/continu du même objet.

"He has a constant/continuous desire of the same object." 
Isabelle Charnavel

\section{Durativity}

a. Annie fait le même repas pour Noël depuis 20 ans. "Annie has made the same meal for Christmas for 20 years."

b. Cela fait longtemps que Marc habite au même endroit.

"Marc has been living at the same place for a long time."

c. Paul a habité au même endroit pendant toute sa jeunesse. "Paul was living at the same place during his whole youth."

d. La durée d'habitation dans le même logement est limitée. "The period of habitation in the same housing is limited."

e. Une habitation prolongée dans le même logement pourrait poser problème.

"Extended habitation in the same housing could pose problems."

In all these cases, the crucial and unifying point is that a plural event is involved, which is distributed over the overall running time in several ways depending on the aspect that is expressed. ${ }^{14}$

Therefore, I claim that the licensing condition for le même is a plural event, ${ }^{15}$ which can be partitioned along different dimensions (participants, times) and même compares the relevant participant in these subevents:

\section{plurality of participants}

Plusieurs étudiants ont lu le même livre.

"Several students read the same book."

There are several subevents of a student reading a book, and each book involved in each subevent is identical to the book of any other subevent.

\section{plurality of times}

Cet étudiant lit souvent le même livre.

"This student often reads the same book."

14 Note that interestingly, the event in (29) (iterativity) is plural only if the presupposition is taken into account. This suggests that même has somehow access to the presupposition.

15 This follows directly if one argues that distributivity is a relative notion: a DP is not distributive per se, but with respect to its event participation (cf. Schein 1993). Moreover, the notion of event is broad here since it has to include states, qualities and nouns.

(xii) Luc et Flore possèdent la même voiture. 'Luc and Flore own the same car.'

(xiii) Voici plusieurs femmes avec la même robe. 'Here are several women with the same dress.'

This fits the notion of event proposed by Schein: nouns are predicates of events. 
On the sentence-internal reading of French le même ('the same')

There are several subevents of this student reading a book, and each book involved in each subevent is identical to the book of any other subevent.

This predicts that singular participants and aspects or adverbial expressions that deny the existence of disjoint intervals of times do not license même. This prediction is borne out: ${ }^{16}$

(35) \#Paul a lu le même livre d'une traite.

"Paul read the same book without stopping once."

So I propose that le même is an existential quantifier over a plural event; this event needs to have independently been distributed through participants or times. Moved to the position between the negation and the event predicate, le même takes two arguments: its restriction $\mathrm{Y}$ and the event predicate $\mathrm{Z}$, and says that for every event $e_{n}$ part of this (obligatorily) plural event, there is ${ }^{17}$ a corresponding individual $x_{n}$ in $e_{n}$ part of the restriction set, and all these individuals $x_{n}$ are identical:

$\llbracket l e m e \hat{e} e \rrbracket=\lambda Y_{<e, t>} . \lambda Z_{<e, v t>} \cdot \exists x_{1}, x_{2}, \ldots x_{n} \leq x\left(n \in \mathbf{N}^{*}\right)$ such that $Y\left(x_{n}\right)=1$ and $Z\left(x_{n}\right)\left(e_{n}\right)=1$, and $x_{n-1}=x_{n}$

Presupposition: $\exists x_{e}$ such that $Y(x)=1$ and $Z(x)(e)=1$

In the following example, this means that it is presupposed that Luc and Flore are reading a book; moreover, it is not the case that for every subevent $e_{1}$ (Luc reading) and $e_{2}$ (Flore reading), there is a book $x_{1}$ and a book $x_{2}$, such that $x_{1}$ is identical to $x_{2}$. Note that the event has been distributed through a silent distributive operator.

Luc et Flore ne lisent pas le même livre.

"Luc and Flore are not reading the same book."

16 Note however that the fact that the silent generic operator does not seem to license le même (xiva) while overt generic operators do (xivb) remains unexplained:

(xiv) a. \#Face à ses patients, un médecin a le même objectif. '\#Facing his patients, a doctor has the same objective.'

b. Face à ses patients, un médecin a généralement le même objectif.

'Facing his patients, a doctor generally has the same objective.'

17 The existential part accounts for the indefiniteness effects of le même. 


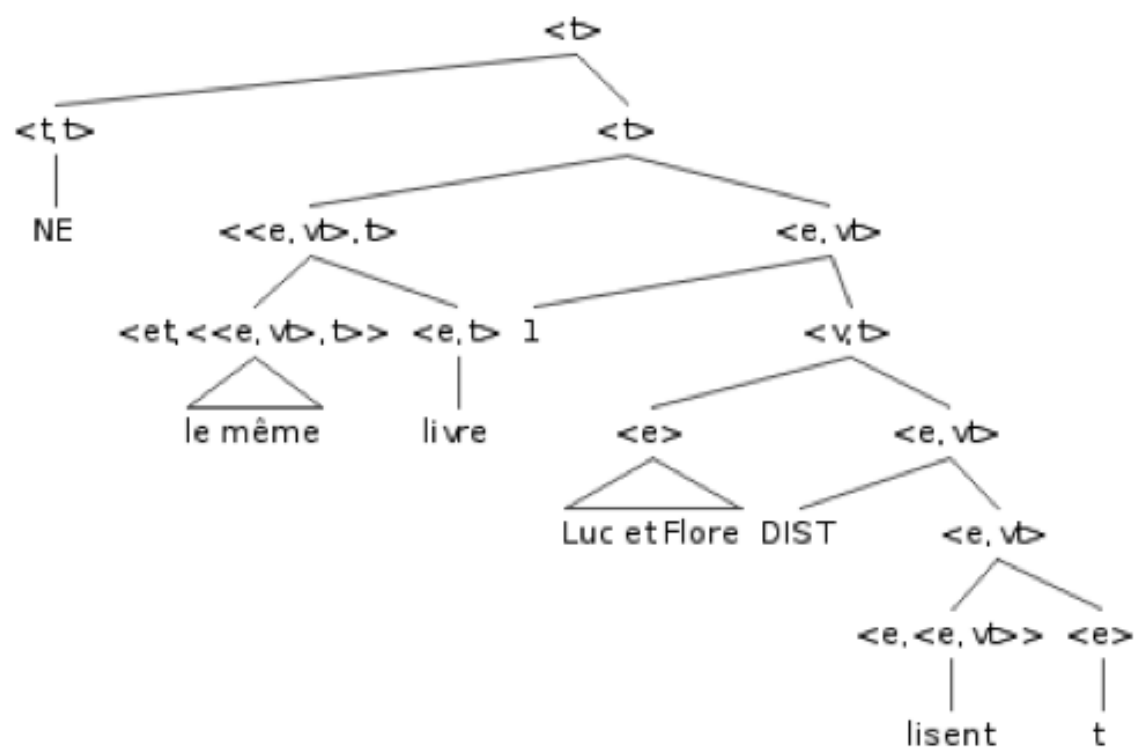

\section{Relation to pluractionality}

The licensing condition for même (plural event distributed through participants or times) suggests that même can be related to the notion of pluractionality. According to Lasersohn (1995), "pluractional markers attach to the verb to indicate a multiplicity of actions, whether involving multiple participants, times or locations [...] We seem to have an analog in the domain of events to the more familiar phenomenon of plurality in the domain of individuals." This means that there is temporal pluractionality (distribution of subevents through times) and non-temporal pluractionality (distribution of subevents through participants).

For example, ${ }^{18}$ the Chechen verbal pluralization process (marked by stem vowel alternations) generates three main semantic interpretations: frequentative, distributive, and durative (cf. Yu 2003), meaning that the pluractionality of the verb can be distributed over participants or times.

18 See Ojeda 1998, Collins 2001, and van Geenhoven 2004 for more examples of pluractionality. 
On the sentence-internal reading of French le même ('the same')

distributive interpretation [Yu 2003: 296]

ceera $\sim$ duezalsh takhana duqa hxaalkhie ghittira

their members of family today very early wake up.PLR.WP

"Their family members woke up very early."

frequentative interpretation [Yu 2003: 296]

(38) iza ocu myriahx duqa hxaalkhie ghittira

he that period very early wake up. PLR.WP

"He often got up very early during that period of time."

Certainly, there is no pluractionality in French in the sense of Chechen (pluractional morphology on the verb that generally signifies multiple actions ${ }^{19}$ ), but the licenser for même is a plural event, which can be partitioned along participants or times. In other terms, it seems that the presence of même is precisely licensed by pluractionality, whether non-temporal (cf. most examples of same in the literature) or temporal (cf. new data provided here). This suggests that the notion of pluractionality is relevant in French too, and thus in languages that lack pluractional markers.

\section{Conclusion}

In this paper, I have focused on the sentence-internal reading of le même and two issues it raises. Concerning the problem of definiteness, I have argued that le même is a complex determiner with specific properties with respect to presupposition and specificity. Concerning the problem of compositionality, I have proposed an analysis in terms of event, based on new data involving aspects: I have claimed that le même is an existential quantifier over an event that has been distributed over participants or times. Finally, I have related this phenomenon to the notion of pluractionality: the new data I mention here relate to the notion of temporal pluractionality (distributivity over times), while the data already mentioned in the literature (for same) relate to the notion of non-temporal pluractionality (distributivity over participants). Therefore, it seems that the notion of pluractionality makes sense in French too. Thus, phenomena such as même can be a way to investigate pluractionality in languages that lack pluractional morphology.

19 Except maybe for some suffixes like -oter or -iller (cf. tapoter 'to tap repeatedly', sautiller 'to hop repeatedly'). 
Isabelle Charnavel

\section{References}

Barker, Chris. 2007. Parasitic scope. Linguistic and Philosophy 30(4). 407-444. doi:10.1007/s10988-007-9021-y.

Brasoveanu, Adrian. 2008. Sentence-internal readings of same/different as quantifierinternal anaphora. In Proceedings of the 27th West Coast Conference on Formal Linguistics (WCCFL), 72-80.

Carlson, Greg. 1987. Same and different: some consequences for syntax and semantics. Linguistic and Philosophy 10(4). 531-565. doi:10.1007/BF00628069.

Charnavel, Isabelle. 2011. On French un même and antispecificity. In Ingo Reich (ed.), Sinn und Bedeutung 15, Saarbrücken, Germany: Unversaar - Saarland University Press.

Collins, Chris. 2001. Aspects of plurality in $¥$ Hoan. Language 77(3). 456-475. doi:10.1353/lan.2001.0141.

Enç, Mürvet. 1991. The semantics of specificity. Linguistic Inquiry 22(1). 1-25. http://www.jstor.org/stable/4178706.

van Geenhoven, Veerle. 2004. For-adverbials, frequentative aspect, and pluractionality. Natural Language Semantics 12(2). 135-190. doi:10.1023/B:NALS.0000031389.36427.af.

Lasersohn, Peter. 1995. Plurality, conjunction and events. Dordrecht: Kluwer.

Moltmann, Friederike. 1992. Reciprocals and same/different: towards a semantic analysis. Linguistics and Philosophy 15(4). 411-462. doi:10.1007/BF00627683.

Ojeda, Almerindo. 1998. The semantics of collectives and distributives in Papago. Natural Language Semantics 6(3). 245-270. doi:10.1023/A:1008289808782.

Schein, Barry. 1993. Plurals and events. Cambridge, Massachusetts: MIT Press.

Solomon, Mike. 2009. Partitives and the semantics of same. Sinn und Bedeutung (SuB) 14 handout.

Yu, Alan. 2003. Pluractionality in Chechen. Natural Language Semantics 11(3). 289-321. doi:10.1023/A:1024997718758.

Isabelle Charnavel

Department of Linguistics

3125 Campbell Hall, UCLA

Los Angeles, CA 90095-1543

icharnavel@ucla.edu 